\title{
Study on Chemical Composition of Centaurea karduchorum Boiss. Species from Endemic Plants of Eastern Anatolia of Turkey
}

\author{
Ruveyde Tuncturk, Murat Tuncturk, Lutfi Nohutcu \\ Van Yuzuncu Yıl University, Agricultural Faculty, Field Crops Department, Van-Turkey \\ *Correspondence: ruveydetuncturk@yyu.edu.tr, (Ruveyde Tuncturk)
}

Published: 29 July 2019

\begin{abstract}
Centaurea karduchorum Boiss species spread naturally in the Van lake in the Eastern Anatolia Region of Turkey and is a perennial endemic species. The leaves are consumed as herbal tea by the local people for the treatment of diabetes. In this study, the nutritional values and mineral compositions of Centaurea karduchorum Boiss which grown as wild plants in the Van region of Eastern Anatolia, Turkey were examined. The chemical characters estimated included as $\mathrm{N}, \mathrm{Na}, \mathrm{Mg}, \mathrm{K}, \mathrm{Ca}, \mathrm{P}, \mathrm{S}, \mathrm{Mn}, \mathrm{Fe}, \mathrm{Cu}, \mathrm{Zn}, \mathrm{Cr}, \mathrm{Cd}, \mathrm{Co}$ as well as total ash, crude protein, crude fiber and $\mathrm{pH}$. A result of the research, ash content, nitrogen content, crude protein content, $\mathrm{pH}$ and crude fiber were obtained as $5.93 \%, 1.75 \%, 10.93 \%, 6.66$ and $32.58 \%$, respectively. Also, the detected some chemical components values were as follows: Potassium content 5.57 $\mathrm{g} /$ phosphorus $1.18 \mathrm{~g} / \mathrm{kg}$, magnesium $5.71 \mathrm{~g} / \mathrm{kg}$, sulphur $1.12 \mathrm{~g} / \mathrm{kg}$, manganese $79.56 \mathrm{mg} / \mathrm{kg}$, zinc 15.18 $\mathrm{mg} / \mathrm{kg}$ and iron $583.56 \mathrm{mg} / \mathrm{kg}$.
\end{abstract}

Key words: Anatolia, mineral elements, Centaurea karduchorum Boiss.

\section{Introduction}

Centaurea karduchorum Boiss. belonged to the Asteraceae (Compositae) which is represented by 1100 genera and about 25000 species in the world. It has a total 1209 species in the flora of Turkey. In terms of the number of species, Asteracea family is the richest family in our country. The genus Centaurea of the Asteracea family is one of the most important genera and Centaurea species are represented by 700 species worldwide. The genus is comprised 189 taxa (Polat, 2010) in Turkey and 111 of them are endemic (Davis et al., 1988; Guner, 2000). The endemism rate of Centaurea L. is approximately $60 \%$. For this reason, the gene center is considered as Turkey (Kose et al., 2010). This plant used as digestion, diuretic, antipyretic, antidiabetic, anti-inflammatory and antibacterial.

Centaurea species are used traditionally for medicinal purposes. Centaurea species are used as single or as mix with other plants. Especially, it is used for the treatment of diseases such as antidiabetic, antidiarrheal, antirheumatic, anti-inflammatory, digestive, stomachic, diuretic, astringent, hypotensive, antipyretic, cytotoxic, cancer, migraine and antibacterial. C. karduchorum Boiss., which is known by the name of the prophet flower in our country, is used for fire-suppressing, appetizing and for being forceful, by the public (Karagoz et al., 2002). C. karduchorum Boiss. family is a perennial endemic species belonging to a genus Centaurea, which the herb grows in a restricted area (Van and Bitlis provinces) of the Eastern Anatolia Region. It has grey tomentose leaves and rose-purple 
scarcely radiant flowers. Local names of plants are Giya brinok. The whole plant (root and all aerial parts) units of Centaurea karduchorum are used, especially, as dried powder that is placed on the injuries for wound healing Also, herbal tea which prepared from leaves of C. karduchorum is rich in phenolic compounds and it is used by the local population in the treatment of diabetes (Dalar and Konczaka, 2012; Dalar et al., 2015).

Although, while $\mathrm{Ca}, \mathrm{Mg}$ and $\mathrm{Na}$ are very necessary metals for human and animal health, some elements ( $\mathrm{Cu}, \mathrm{Zn}, \mathrm{Mn}$, Mo etc.) are essential for the organisms. In their absence both growth and reproduction are stopped (Bat et al., 1999). They have poison effect when they reach certain levels the heavy metals such as $\mathrm{Cr}, \mathrm{Pb}, \mathrm{Cd}, \mathrm{Co}, \mathrm{Hg}, \mathrm{Ni}$ in the plants (Ozcan, 2004; Bedir 2010). Until today, there are no reports about chemical composition of the Centaurea karduchorum Boiss species. The aim of this study was to determine the nutritional values and mineral compositions of Centaurea karduchorum Boiss species which grew as wild plants in the Van region of Eastern Anatolia, Turkey.

\section{Material and Methods}

Some chemical compositions of Centaurea karduchorum Boiss which located in natural flora at around Van Lake in Eastern Anatolia Region, were determined. The plants were collected from natural flora in 2013 and botanical identifications were made by the Department of Biology, Science Faculty, Van Yuzuncu Yil University according to 'Flora of Turkey' (Davis, 2007). Some information for C. karduchorum Boiss species are given in Table 1.

Table1. Some introductory information of $C$. karduchorum Boiss species

\begin{tabular}{lccccc}
\hline Plant Scientific Name & Family & Local Name & Used Part & Locality & Col. No. \\
\hline Centaurea karduchorum Boiss & Asteracea & $\begin{array}{c}\text { Peygamber çiçeği, } \\
\text { Giya Brinok }\end{array}$ & $\begin{array}{c}\text { Above } \\
\text { ground }\end{array}$ & B9 & MU5188 \\
\hline
\end{tabular}

B9: VAN, Gürpınar, southern slopes of the Basat mountain, 2600m, MU5188

Plants were cleaned from foreign materials, separated to parts used and washed with deionized water, dried in room temperature, ground, packaged in plastic bags and kept in desiccators until analysis. To determine dry matter content, the materials were dried at $105{ }^{\circ} \mathrm{C}$ for 24 hours in oven. Electric Muffle Furnace set at $550{ }^{\circ} \mathrm{C}$ were used for determination of total ash content (inorganic matter). Kjeldahl apparatus and method were used to find the nitrogen content of the samples. After total nitrogen content determination, crude protein contents were calculated by formula. $\mathrm{pH}$ values were determined by $\mathrm{pH}$-meter in the plant samples. Crude fiber analyses were accomplished by AOAC (Association of Analytical Chemists) method (AOAC, 2000). Mineral compositions of the samples were determined as follows; dried plant samples were ashed in a furnace by nitric (AR) and hydrochloric acid (AOAC). Afterwards, distilled water (50 $\mathrm{ml}$ ) was added to samples in a volumetric flask. All the analyses were repeated three times and standard materials were used for chemical analyses. Atomic Absorption Spectrometry was used for determination of mineral contents. Phosphorus (P) was determined by molybdate-vanadate and sulphur (S) was observed according to the Mitchell, 1992 method in conjugation with a UV-Visible spectrophotometer (Shimadzu 
UV-1201 V; Shimadzu, Kyoto, Japan). The average data obtained from chemical analyses have been shown in Table 2 with their standard deviations.

\section{Results and Discussion}

In the experimental, nutrient content of Centaurea karduchorum Boiss species that is used as a medicinal plant mostly were investigated and some properties such as the values of total ash, total nitrogen, crude protein, $\mathrm{pH}$ and crude fiber contents are given in Table 2 and mineral compositions in Table 3 . The values are given as mean $\pm \mathrm{SD}$.

Table 2. The average chemical composition values of $C$. karduchorum Boiss.

\begin{tabular}{|l|l|}
\hline Parameters & Centaurea karduchorum Boiss. \\
\hline Total ash (\%) & $5.93 \pm 0.058$ \\
\hline Total nitrogen (\%) & $1.75 \pm 0.130$ \\
\hline Crude protein (\%) & $10.93 \pm 0.815$ \\
\hline $\mathrm{pH}$ & $6.66 \pm 0.000$ \\
\hline Crude fiber (\%) & $32.58 \pm 0.021$ \\
\hline
\end{tabular}

According to the results of the study; the total ash, total nitrogen, crude protein, $\mathrm{pH}$ and crude fiber contents of $\mathrm{C}$. karduchorum Boiss situated in Van flora were as 5.93\%, $1.75 \%$, $10.93 \%, 6.66$ and $32.58 \%$, respectively. In previous scientific studies, total nitrogen and crude protein content of some medicinal and edible plants were found in intervals of 0.20 $1.76 \%$ and 1.30-11.56 \%, respectively (Sekeroglu et al., 2006; Tuncturk et al., 2017). Also, Ylldırım et al., 2001 found that pH values varied between 3.50-6.50, Vishwakarma and Dubey, 2011 were reported that crude fiber contents varied between 0.90 to $28.59 \%$ in some medicinal and aromatic plants. Conclusions obtained from our study are compatible with the previous scientific reports on medicinal and aromatic plants.

In the results of study, $\mathrm{Na}, \mathrm{Mg}, \mathrm{K}, \mathrm{Ca}, \mathrm{P}$ and $\mathrm{S}$ contents were determined as $0.44,5.71,5.57$, 24.23, 1.18 and $1.12 \mathrm{~g} / \mathrm{kg}$ from Centaurea karduchorum species, respectively. Nutrition contents of the plants are affected from a number of factors such as plant genetic structure, growing conditions, soil characteristics, water availability, growing seasons etc. Thus, great variability in mineral compositions of the plants and their different parts is expected. This phenomenon has been supported by scientific reports (Ylldırım et al., 2001). Nutrition element concentration values of some medicinal plants obtained from previous studies were summarized for above minerals here: Sodium ( $\mathrm{Na}$ ) concentrations varied from 0.21 to $63.32 \mathrm{~g} / \mathrm{kg}$; magnesium (Mg) values of medicinal and edible plants were found between 1.17 and $86.43 \mathrm{~g} / \mathrm{kg}$ (Akgunlu, 2012). Potassium (K) content changed between 4.34-557.91 g/kg in wild vegetables (Tuncturk et al., 2017; Akgunlu, 2012; Tuncturk et al., 2017; Tuncturk et al., 2017; Tuncturk et al., 2017). Calcium (Ca) concentrations were found in a wide range from 0.03 to $777.52 \mathrm{~g} / \mathrm{kg}$ (Koca et al., 2009; Kayalar et al., 2014; Tuncturk et al., 2017); phosphorous (P) contents varied from 1.1469.13 g/kg (Akgunlu, 2012; Yorgancilar, 2009; Tuncturk et al., 2017; Tuncturk et al., 2017; Tuncturk et al., 2017; Tuncturk et al., 2017); sulphur (S) concentrations were reported in the range of 1.22-108.01 g/kg (Koca et al., 2009; Kayalar et al., 2014; Tuncturk et al., 2017; Tuncturk et al., 2017; Tuncturk et al., 2017; Tuncturk et al., 2017). Macro element concentrations of some medicinal and wild edible plants reported in previous studies 
were summarized above. When compared with the results of them, our findings are agreeing with the results of researches. In the recent studies related to Centaurea species, Kayalar et al., 2014 stated that mineral compositions of different Centaurea species $(C$. calolepis C. lydia C. polyclada) values were as follow: sodium content $1.10-1.41 \mathrm{~g} / \mathrm{kg}$, magnesium 1.45-1.95 g/kg, phosphorus $1.11-1.94 \mathrm{~g} / \mathrm{kg}$, sulphur $1.22-2.57 \mathrm{~g} / \mathrm{kg}$, potassium 10.66-12.84 g/kg and calcium 6.60-25.49 g/kg. Manganese which acts as a coenzyme in a very small amount in our body and facilitates various metabolic processes has the $79.56 \mathrm{mg} / \mathrm{kg}$ content and cupper which plays a role in protein synthesis and energy production was determined as $17.06 \mathrm{mg} / \mathrm{kg}$ from Centaurea karduchorum Boiss. Kayalar et al., 2014 stated that the manganese and iron contents of different Centaurea species (C. calolepis, C. lydia and C. polyclada) were between $158.4-256.0 \mathrm{mg} / \mathrm{kg}$ and 91.2$1317.0 \mathrm{mg} / \mathrm{kg}$, respectively.

Table 3. Mean values of mineral compositions of $C$. karduchorum Boiss

\begin{tabular}{|l|l|}
\hline Minerals & Centaurea karduchorum Boiss. \\
\hline $\mathrm{Na}(\mathrm{g} / \mathrm{kg})$ & $0.44 \pm 0.023$ \\
\hline $\mathrm{Mg}(\mathrm{g} / \mathrm{kg})$ & $5.71 \pm 0.443$ \\
\hline $\mathrm{K}(\mathrm{g} / \mathrm{kg})$ & $5.57 \pm 0.268$ \\
\hline $\mathrm{Ca}(\mathrm{g} / \mathrm{kg})$ & $24.23 \pm 1,438$ \\
\hline $\mathrm{P}(\mathrm{g} / \mathrm{kg})$ & $1.18 \pm 0.060$ \\
\hline $\mathrm{S}(\mathrm{g} / \mathrm{kg})$ & $1.12 \pm 0.032$ \\
\hline $\mathrm{Mn}(\mathrm{mg} / \mathrm{kg})$ & $79.56 \pm 1.158$ \\
\hline $\mathrm{Fe}(\mathrm{mg} / \mathrm{kg})$ & $583.56 \pm 11.170$ \\
\hline $\mathrm{Cu}(\mathrm{mg} / \mathrm{kg})$ & $17.06 \pm 1.136$ \\
\hline $\mathrm{Zn}(\mathrm{mg} / \mathrm{kg})$ & $15.18 \pm 1.018$ \\
\hline $\mathrm{Cr}(\mathrm{mg} / \mathrm{kg})$ & $1.13 \pm 0.015$ \\
\hline $\mathrm{Co}(\mathrm{mg} / \mathrm{kg})$ & $1.14 \pm 0.156$ \\
\hline $\mathrm{Cd}(\mathrm{mg} / \mathrm{kg})$ & $0.12 \pm 0.015$ \\
\hline
\end{tabular}

In our research, the $\mathrm{Zn}$ which has an important role in the formation of RNA and DNA and the conversion into energy of proteins has been identified as $15.18 \mathrm{mg} / \mathrm{kg}$ and the $\mathrm{Fe}$ content that strengthened the immune system was obtained as $583.56 \mathrm{mg} / \mathrm{kg}$ from Centaurea karduchorum Boiss. For some Centaurea species zinc (Zn) values were reported between 1.0 and $48.5 \mathrm{mg} / \mathrm{kg}$ and cupper contents were determined between 22.50 and $60.0 \mathrm{mg} / \mathrm{kg}$ (Kayalar et al., 2014). In this study, determined concentrations of the minerals are in accordance with previous studies.

Analyzed plant samples had limited and trace levels of chromium (Cr), cadmium (Cd) and cobalt (Co) as 1.13, 0.12 and $1.14 \mathrm{mg} \mathrm{kg}-1$, respectively. These metals known as heavy metals and their hazardous effects on living organisms in certain quantities were reported. Cr concentrations of some edible and medicinal plants were found as 0.05-19.10 $\mathrm{mg} / \mathrm{kg}$ (Koca et al., 2009; Tuncturk et al., 2017). Cd concentrations were reported between 0.04-0.440 mg kg-1 for medicinal plants and wild vegetables (Lozak et al., 2002; Tuncturk et al., 2017). Co concentrations of some medicinal and edible plants were stated in previous studies in the ranges of $0.047-1.69 \mathrm{mg} / \mathrm{kg}$ (Akgunlu, 2012). Heavy metal concentrations of the analyzed plant samples are found some lower than previous studies findings. 


\section{Conclusion}

The use of Centaurea species which have a wide natural distribution area on the earth is very common due to its medical effects in our country and which is consumed as an herbal medicine. The effects of these crops on human health should be investigated. For their use attention and conscious consumption should be ensured. Macro and micro elements must be present in the plant as both functional and structural elements of the plants. According to our study, it was determined that Centaurea karduchorum Boiss which is an endemic plant belonging to Eastern Anatolia, in terms of macro and micro minerals is rich. However, the heavy metal concentrations were low in the plant. The concentration of the following metals: $\mathrm{Cr}$, Cd and Co were within permissible limit of WHO.

\section{References}

AOAC, 2000. Official Method of Analysis 962.09 (17 th Edition) Volume I. Association of Official Analytical Chemists, Inc., Maryland, USA.

Akgunlu, S. B., 2012. Mineral Content and Microbiological Analysis of Some Wild Edible Vegetables Consumed in Kilis and Gaziantep Provinces in Graduate School of Natural and Applied Sciences, Kilis 7Aralik Univ.

Bat, L., Çulha M., Öztürk, M., 1999. Heavy Metals. Süleyman Demirel Üniversty, Eğirdir Water Product Faculty Jornal, 6: 166-175.

Bedir, N., 2010. Analysis of Heavy Metals in Open and Packed Tea by ICP-OES.Sakarya University, Department of Chemistry, Master Thesis, Sakarya.

Dalar, A., Konczaka, I., 2012. Botanicals from Eastern Anatolia Region of Turkey: Antioxidant capacity and phenolic constituents of endemic herbal medicines. Journal of herbal medicine 2: 126-135.

Dalar, A., Uzun, Y., Mukemre, M., Turker, M., Konczaka, I., 2015. Centaurea karduchorum

Boiss. from Eastern Anatolia: Phenolic composition, antioxidant and enzyme inhibitory activities. Journal of Herbal Medicine 5: 211-216.

Davis, P.H., R.R. Mill., K. Tan., 1988. Scorzonera L. In: Flora of Turkey and East Aegean Islands (supplement I). Davis, P.H. and R.R. Mill (Eds.). Edinburgh Univ. Pres, Edinburgh, p.p. 169-170.

Davis, P.D., 2007. Flora of Turkey and the East Aegean İslands. Edinburgh: Edinburgh University Press. 4.

Guner A., 2000. Centaurea L. In: Guner A, Ozhatay N, Ekim T \& Başer KHC (eds.) Flora of Turkey and the East Aegean Islands (Supplement 2). Edinburgh: Edinburgh University Press, p.p. 163-164.

Karagoz, A., Cevahir, G., Ozcan, T., Sadıkoğlu, N., Yentür, S., Kuru, A., 2002. Evaluation of Antiviral Activity Potentials of Aqueous Extracts Prepared from Some High Plants, 14. Herbal Drug Raw Materials Meeting, Proceedings, May, Eskisehir.

Kayalar, H., Durmuskahya, C., Hortooğlu, Z. S. 2014. Mineral Compositions of Some Selected Centaurea species from Turkey. Asian Journal of Chemistry; Vol. 26, No. 16: 5317-5318.

Koca, U., Ozkutlu, F., Sekeroglu, N. 2009. Mineral Composition of Arnebia densiflora(Nordm.) Ledeb. An Endemic Medicinal Plant from Turkey Biomed. 4 (1): 51-56.

Kose, Y. B., Alan, S., Yucel, E., 2010. Comparative Investigation of the Morphological Characteristics of Species belonging to the Centaurea L. Section Phalolepis (Cass.) DC. Biological Diversity and Conservation. 3/1: 10-22.

Lozak, A., Soltyk, K., Ostapczuk, P., Fijalek, Z. 2002. Determination of selected trace elements in herbs and their infusions, Science of The Total Environment. 289 (1-3): 33-40.

Mitchell, C.C., 1992. Plant Analysis Reference Procedures for the Southern Region of the United States. Southern Cooperative Series Bulletin no: 368. Determination of sulfur in plant tissue by turbidimetry. The University of Georgia Crops and Soil Science Dept., Athens GA.

Ozcan, M., 2004. Mineral Contents of Some Plants Used as Condiments in Turkey. Food Chem. 84: 437-40.

Polat, M., 2010. Karyotype Analyses Of Centaurea Cadmea Boıss., Centaurea Fenzlı Reichardt And Centaurea rigida Banks \& Sol. (Compositae) Species. Selçuk University Graduate School of Natural and Applied Sciences Department of Secondary Science and Mathematics Education.

Sekeroglu, N., Ozkutlu, F., Deveci, M., Dede, O., Yilmaz, N., 2006. Evaluation of some Wild Plants Aspect of Their Nutritional Values Used as Vegetable in Eastern Black Sea Region of Turkey, Asian Journal of Plant Sciences. 5 (2): 185-189. 
Tuncturk, R., Tuncturk, M., Eryiğit, T., 2017. Study on Chemical Composition of Teucrium Species in Van Region International Ecology and Environmental Congress.12-15 September, Oral presentation, $\mathrm{p}: 41$.

Tuncturk, M., Celen, E., Tuncturk, R., 2017. Nutrient Content Of Three Edible Wild Plants.From Polygonaceae Family. Oxidation Communications 40, No 1-II, 327-334.

Tuncturk, R., Tuncturk, M., Sekeroglu, N., Eryigit, T., Ozgokce, F., 2017. Investigation of Some Chemical Characteristics of Wild Edible Cephalaria Schrader Ex Roemer \& Schultes G.C. Setosa Boiss \& Hohen Grooving in East Anatolia. Indian Journal of Pharmaceutical Education and Research, 51: 333-337.

Tuncturk, R., Tuncturk, M., Eryigit, T., Karik, U., 2017. Study on Chemical Compositions of Acillea Species in East Anatolia. Jatuspab-2 (The Second Japan-Turkey International Symposium on Pharmaceutical and Biomedical Sciences). Oral presentation, September 11th - 12th, Trabzon- Turkey.p: 98.

Vishwakarma, K. L., Dubey, V., 2011. Nutritional analyses of indigenous wild edible herbs used in Eastern Chhattisgarh India. Emir., J. Food Agric. 23 (6): 554-560.

Yıldırım, E., Dursun, A., Turan, M., 2001. Determination of the nutrition contents of the wild plants used as vegetables in upper Çoruh Valley, Turkish Journal of Botany. 25: 367-371.

Yorgancilar, M., 2009. Mineral ingredients of debittered termiye seeds (Lunipus albus L.) In Selçuk Agriculture and Food Sciences Magazine. 